\title{
Development of a compact pulsed ejector: performance assessment from measured aerodynamic characteristics
}

\author{
N. F. Yurchenko • P. M. Vynogradskyy \\ Laboratory for Advanced Aerodynamics and Interdisciplinary Research, Institute of Hydromechanics, Nat. Academy of Sci., \\ Kyiv, Ukraine
}

Received: 15 April 2020 / Accepted: 25 May 2020

\begin{abstract}
The investigation aims at the development of an efficient ejector applicable to the inflation system of automobile airbags. The work consists in the design of the ejector together with an appropriate testing facility and a measurement complex. The experiment is planned in three parts, measurement of pressure fields, high-speed video recording of the airbag inflation using the designed ejector, and measurement of the entrainment (aspiration) ratio. For that, a few basic elements are built. They are the pneumatic facility with a specially designed high-speed valve as its key element, the data acquisition, and processing system controlled remotely to analyze pressure probe rake signals, and the stand to measure entrainment ratio values depending on the ejector geometry and motive pressure values.

To satisfy the given engineering requirements, supersonic pulse aspirators are developed in various design versions, manufactured, and tested in the Laboratory for Advanced Aerodynamics. Analysis of a number of experimentally obtained results showed their good mutual concordance and a possibility to get the "cold-gas" aspiration ratio, $A=3.16-1.57$, depending on the motive pressure. The new device has obvious advantages compared to the conventional pyrotechnic type: (1) provides their safe operation with big airbags of the autonomous car, (2) eliminates injuries to occupants since aspirated airbags stop inflating on contact with any object within a vehicle.
\end{abstract}

Keywords: pulse ejector, airbag inflation, measurement, pressure fields, entrainment (ejection, aspiration) ratio

\section{Introduction}

A supersonic pulse aspirated ejector (inflator) is developed for a driver's airbag with the potential to be used in airbags of any bigger sizes [1, 2]. It should initiate air aspiration from a car compartment into the $50-60 \mathrm{~L}$ airbag to inflate it within $30-50$ ms with the aspiration ratio above 4 . The ejector model is designed on the basis of PrandtlMayer flow analysis, in particular, using the generation of simple suction waves at a sharp edge of an expansion area.

Investigations were carried out as the combined numerical and experimental modeling. Numerical recommendations outlined essential design features of models that were developed into aspirator design drawings, fabrication, and further testing of models. Experiments were fulfilled in a specified facility driven by compressed air with a high-speed cutoff which was built in the Laboratory for Advanced Aerodynamics \& Interdisciplinary Research. Multi-stage multivariate analysis of calculated and measured flow fields in a number of models under consideration aimed at optimization of the aspirator geometry and its operational parameters.

As a result of successive design modifications, the concept feasibility was proven to satisfy the engineering requirements.

Following formulated recommendations, parallel experiments using a small gas generator to initiate air entrainment are held in the Shanghai East Joy Long Motor Company.

\section{Introduction}

The supersonic pulse ejector operation consists in the ambient air entrainment by the high-velocity primary jet flow. The two flows interact in a mixing chamber of a diffuser type and become completely mixed at the exit from the

N. F. Yurchenko

nina.yurchenko@gmail.com

The article is distributed under the terms of the license CC BY 4.0. 
mixing chamber. Correct design of all the constituent elements, a supersonic nozzle, a prechamber, a mixing chamber, and their couplings contribute to the ejector efficiency together with properly chosen basic flow parameters. Complicated processes in the ejector-diffuser system including flow unsteadiness, turbulent mixing, and compressibility effects require special efforts to optimize the system operation that in general is characterized by relatively low efficiency.

Understanding of these processes is of practical importance in applications, in particular, in the automotive industry: such an ejector can be a part of the novel airbag inflation system. As such, it will provide greater safety on the roads in a greater range of its applicability. The latter is especially fair for the explosively growing interest in autonomous cars equipped with a number of big airbags that requires the development of a new approach to their operation. Airbags controlled by aspirated inflators require smaller gas generators (of $1 / 3$ size) compared to the conventional gas generators; they will not harm occupants located randomly inside the compartment and will eliminate satellite crash sensors and occupant sensors [3]. It is schematically illustrated in Fig. 1.

Thus the goal of this work is to develop a supersonic pulse aspiration system and to optimize it for a driver's airbag providing inflation of the $50-60 \mathrm{~L}$ airbag within $~ 30$ ms with the aspiration ratio $\mathrm{A} \geq 4$ (Fig. 2).

The basic complexity to solve this problem consists in limitations imposed by every one of these requirements onto the others. Thus the only possible approach to find a satisfactory problem solution is a search of optimal compromises between separate engineering solutions.

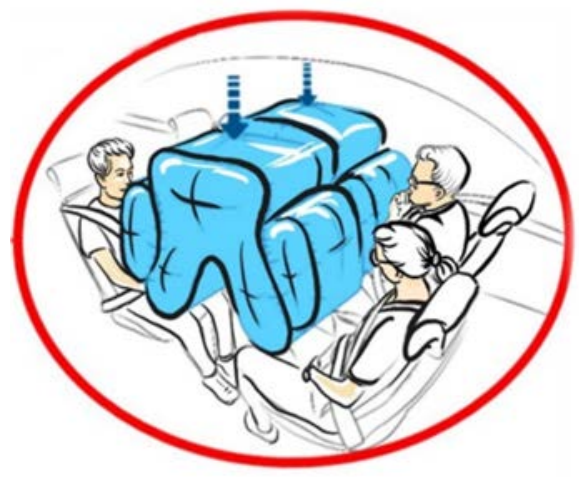

Fig. 1. Operation of airbags with an aspirated inflator system in autonomous cars: reduced cabin pressure, no harm to occupants [2, 3]

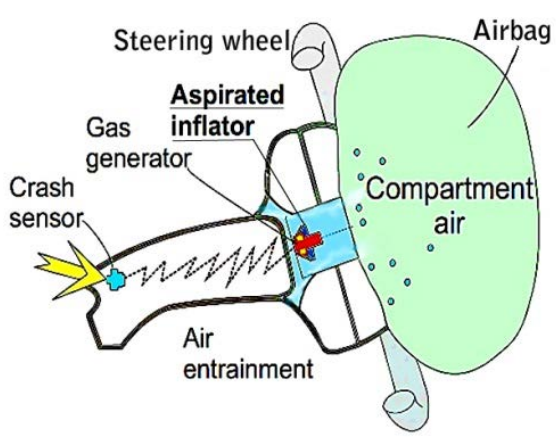

Fig. 2. Aspirated inflator operation based on the entrainment of ambient air using the supersonic pulse ejector

\section{Investigation strategy}

The investigations are planned as interconnected numerical and experimental studies on the basis of the engineering requirements formulated for the resultant device. They start from the numerical evaluations of operation modes and corresponding design elements [4]. The sought engineering solutions are to be essentially different from those typical for stationary flow modes due to different physical nature of processes characterizing pulse supersonic flow interaction with the entrained secondary flow $[5,6]$.

Basic elements of an axisymmetric supersonic pulse aspirator that require special design efforts are as follows.

- The geometry of the jet-forming ring-type slit and its coupling with a high-pressure zone. The design should enable the passage of a pressure shock at the moment of the aspirator launch as well as the formation of a resultant ejecting flow at given parameters.

- A numerical evaluation of the design is made for two temperature regimes. The hot gas case models gas generator operation to produce the jet with according parameters. The cold gas case models the situation of compressed gas experiments in accordance with relevant parameter values.

- Coupling of the slit with a diverging nozzle; determination of nozzle and mixing chamber geometry producing required flow patterns to form the flow entrainment with a given flow rate and aspiration ratio.

- Matching of an inlet length and the shape of the axisymmetric aspirator at the atmospheric input pressure with the geometry and gas-dynamic characteristics of its nozzle part.

- Coupling of an axisymmetric aspirator outlet with an airbag to provide a required excessive pressure in the given airbag.

Being roughly evaluated, the design parameters are formulated as a guide to further engineering design and experimental testing of the developed ejector model (see e.g. Fig. 3 [4]). 
The experimental testing aims at validation and corrections of given numerical estimates in terms of the designed model operability in a given range of gas-dynamic parameters. After the aspirator design drawings are developed, several models are manufactured with the consecutively modified aspirator parts and their couplings such as shapes and dimensions of its nozzle, pre-chamber, mixing chamber, etc.

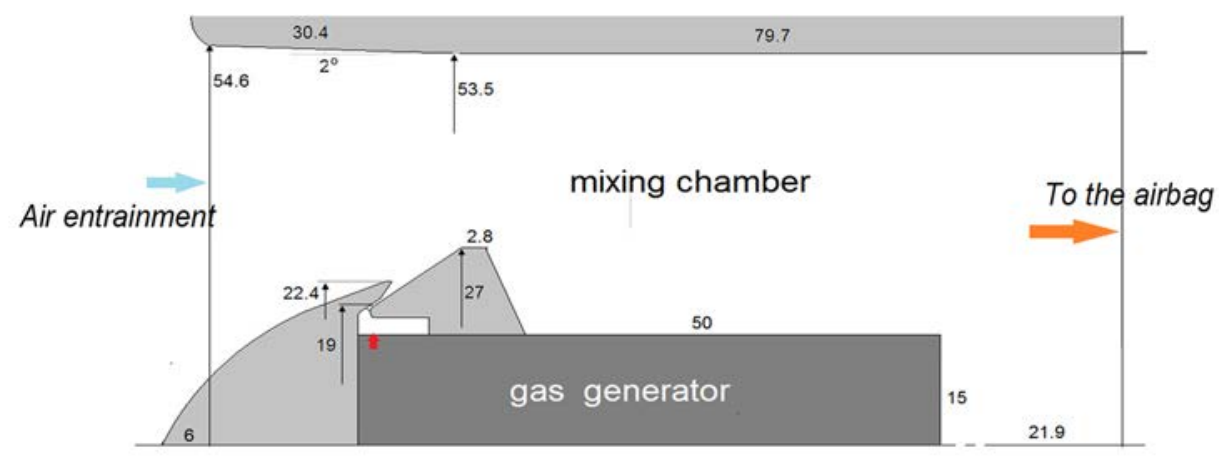

Fig. 3. Numerically recommended aspirator design with a set of linear and angular dimensions

The measurement program embraces 3 separate tasks mutually connected through certain model design features and parameters as well as the range of motive pressure, $\mathrm{P}_{\mathrm{m}}$ :

- measurement of pressure fields in the aspirator system,

- measurement of entrainment/aspiration ratio,

- high-speed video-recording of the airbag inflation using the developed aspirator.

The basic experimental effort is focused on the determination of optimal values of operational (motive) pressure for the given aspirator geometry. Patterns of measured pressure fields using distributed pressure probes enable to determine a dominant jet location within the aspirator housing (mixing chamber) and to recommend optimal sets of parameters. Stable behavior of the supersonic jet within 30-40 ms implies a stable entrainment/aspiration process which is not essentially deteriorated with flow separation or relocation of the initiating jet. Conclusions on the aspirator operability and recommendations on its design are substantiated with measured aspiration ratios and video-recorded inflation process of an airbag.

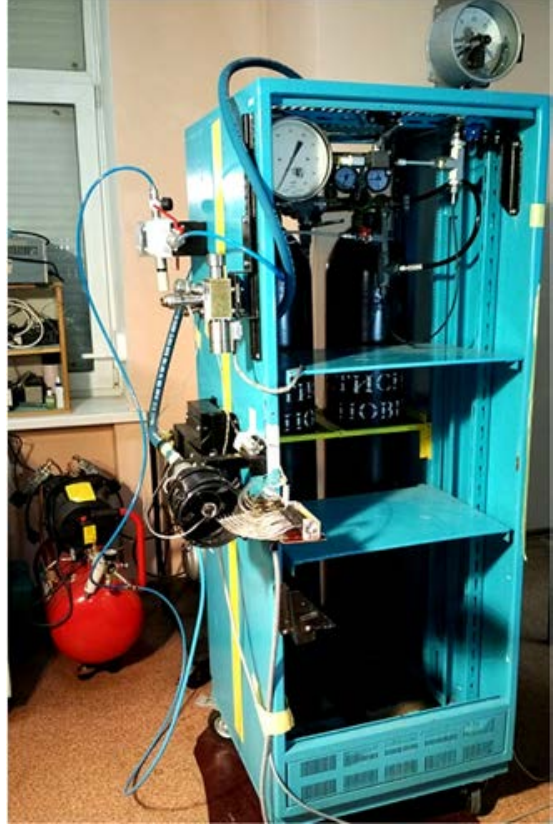

Fig. 4. Experimental facility: 1 - aspirated inflator model; 2 - pressure probe rake; 3 - high-speed valves;

4 - two compressed air tanks, 0-100 bar; 5 - high- and low pressure compressors

\section{Experiment arrangement}

A dedicated pneumatic experimental facility (Fig. 4) was designed and fabricated to test developed ejector systems [7, 8]. It includes high-pressure tanks (250 bar), reduction valve, receiver (150 bar), pressure gauges, a high-speed valve, high- and low-pressure compressors, data acquisition and processing system, high-speed camera.

The specially designed UHSV-1 high-speed valve is electronically controlled. The time from the valve powering (control signal) to the start of the opening is $12 \mathrm{~ms}$. Its characteristics are given in Table 1.

Table 1. High-speed valve technical parameters

\begin{tabular}{|l|c|}
\hline Opening time & $2-4 \mathrm{~ms}$, max \\
\hline Closing time & $3-5 \mathrm{~ms}$, max \\
\hline Pressure range & $1-65 \mathrm{~atm}$ \\
\hline Temperature range & $+5{ }^{\circ} \mathrm{C} \div+65^{\circ} \mathrm{C}$ \\
\hline Voltage & $80 \pm 6 \mathrm{~V}$ \\
\hline Material & Steel $14 \times 17 \mathrm{H} 2$ \\
\hline Throat diameter & $20 \mathrm{~mm}$ \\
\hline Mounting & Thread: $7 / 8^{\prime \prime}$ \\
\hline Dimensions & $79 \mathrm{~mm} \mathrm{X} 125 \mathrm{~mm} \mathrm{X} 141 \mathrm{~mm}$ \\
\hline Weight & $3 \mathrm{~kg}$ \\
\hline
\end{tabular}


The high-speed valve is the key element of the facility for testing airbag inflation using aspirated inflators. It is developed to mimic the supersonic jet generation in the automotive inflation system using the pyro-cartridge [9]. Thus the valve operation must provide adequately short opening and closing path from the high-pressure source 4 in Fig. 4 to the aspirated inflator 1 to form a jet flow within 20-40 ms initiating the ambient air entrainment. Under these conditions, the so-called "cold gas" experiments in the pneumatic facility can be considered identical to the "hot gas" testing. Consequently, it will enable us to analyze and compare results obtained numerically for both cases with the measurement results. Besides, it can give a clue to the extrapolation of experimental cold-gas data to the practical hotgas case taking into account their different gas-dynamic parameters.

\section{Measurement complex}

Data acquisition, processing and control system (DAS) is designed to launch and control the whole measurement process. It is integrated into the measurement complex of the Advanced AIR laboratory [7, 9, 10, 11]. Fig. 5 shows a block diagram of the part related to the discussed tasks. In these tests, a PCI-1710 multifunctional data acquisition board is used to generate control signals (two digital outputs, DO) and measure up to 15 signals of the pressure probes via 15 analog input (AI) channels. Analog input channel \#00 is used to register the control signal simultaneously with the pressures. Fig. 6 shows the realized DAS layout blocks and details.

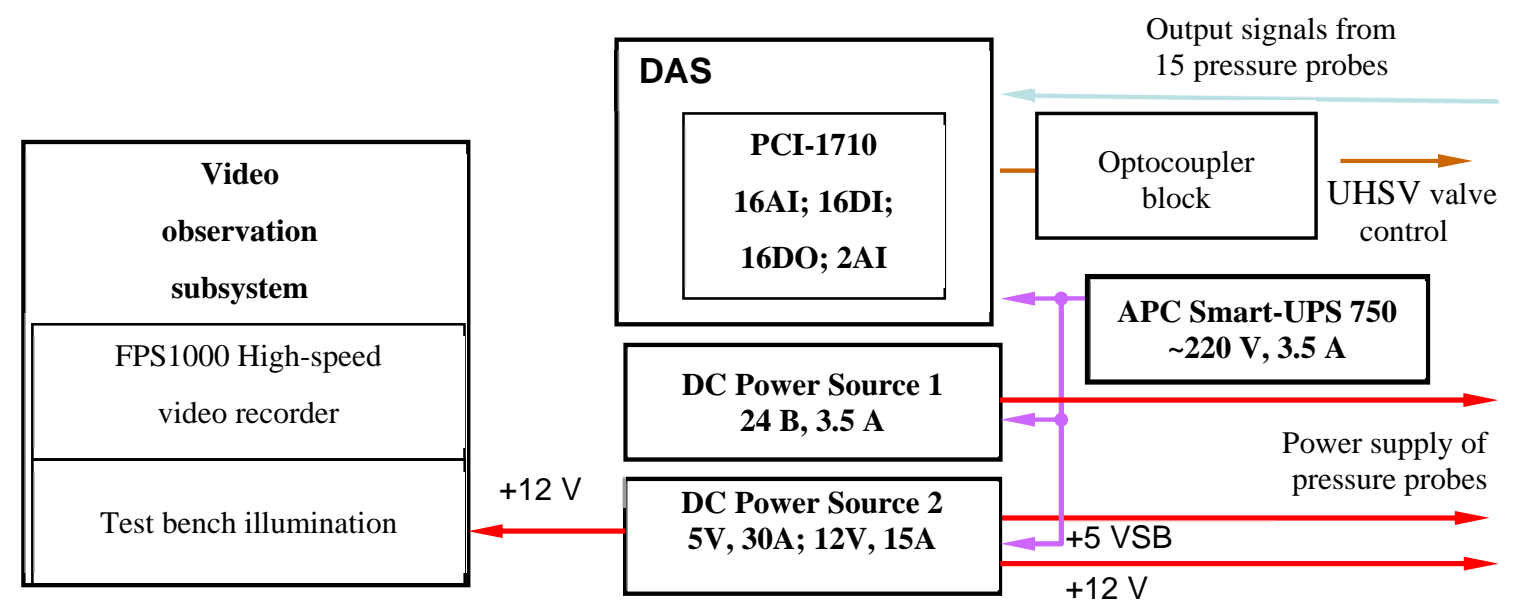

Fig. 5. Block-diagram of Data Acquisition \& Processing System (DAS) to test airbag inflation systems

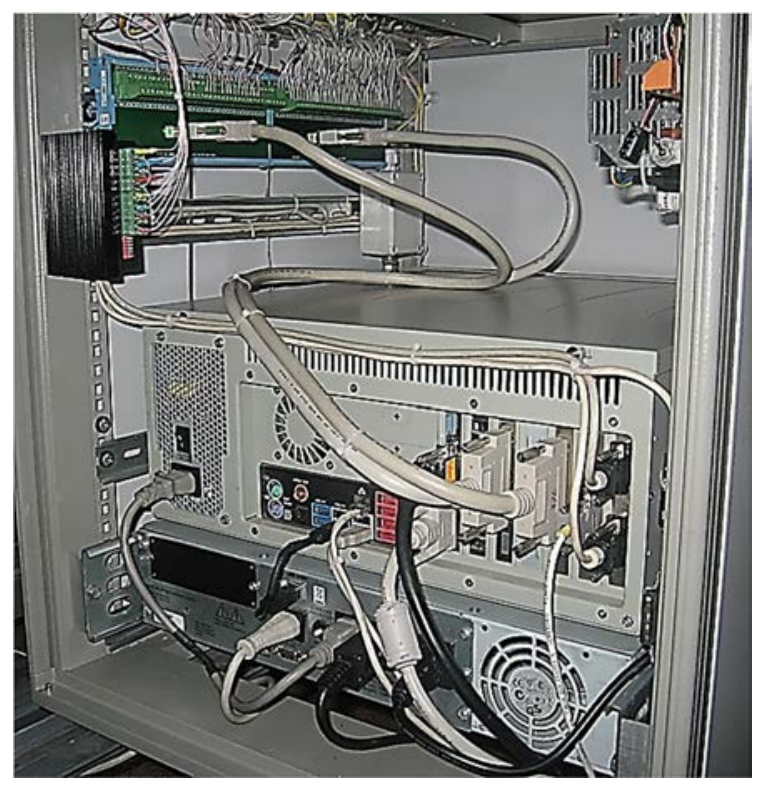

$a$

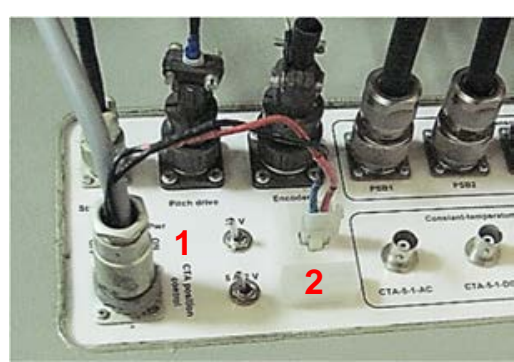

$b$

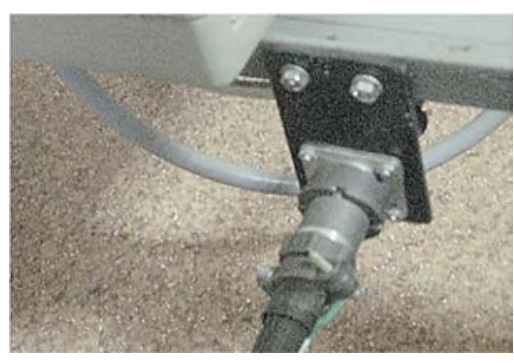

$C$

Fig. 6. DAS layout: $(a)$ general DAS layout, back view; $(b)$ control cable 1 and power source connection 2; (c) analog input cable connection 
The LabView software is used to control the experimental tasks and to measure analog signals. The data postprocessing and presentation of the results is performed using the Matlab software package.

\section{Aspirator test models}

Several aspirator models were designed, manufactured, and tested what is partly described in Breed, 2015. The first set is characterized as aspirators with an external slit [7] where the circumferential nozzle defines the overall size of an aspirator normally to its axis. The second type combines aspirators with an internal ejecting slit/nozzle. The results discussed here are obtained for the internal-slit models of Fig. 7 type. Key geometry versions of two internal-slit aspirators are shown in Figs. 7, $a, b$. The sharp bend edge responsible for Prandtl-Mayer conditions is provided by the coupling of two surfaces A and B of the metal disks \#1 and \#2 [3, 4].

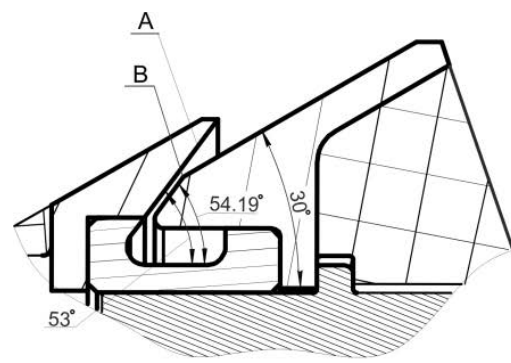

$a$

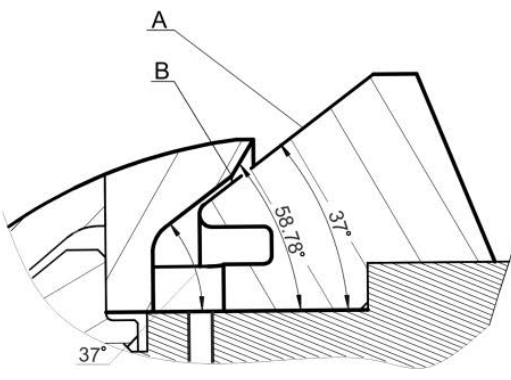

$b$

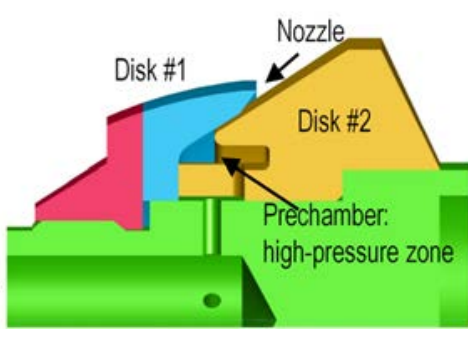

$c$

Fig. 7. Geometry of the ejector nozzle, $(a)$ and $(b)$; components of the operational zone, $(c)$

Variable parameters during testing include motive pressure values and minute design modifications. The overall dimensions of the system remain the same as defined by an engineering requirement to locate the system within a steering wheel, i.e. the aspirator length is $117 \mathrm{~mm}$, its diameter is $120 \mathrm{~mm}$. The variable design elements are angular and linear sizes of coupling metal disks \#1 and \#2:

- $\quad$ an operating angular size of the metal disk \#1 (blue in Fig. 7, c) was changed within $\sim 20^{\circ}$;

- one angle of metal disk \#2 varies accordingly, two other angles were modified;

- width of a nozzle slit could be changed in a course of experiments within 0.3-0.5 mm with a step of $0.05 \mathrm{~mm}$;

- internal geometry housing (mixing chamber): the initial confusor type shape can be conjugated with a cylinder or with a diffusor.

The fabricated model of the aspirated inflator (without a housing/mixing chamber) is shown in Fig. 8, $a$ while Fig. 8, $b$ illustrates the principle of its operation.

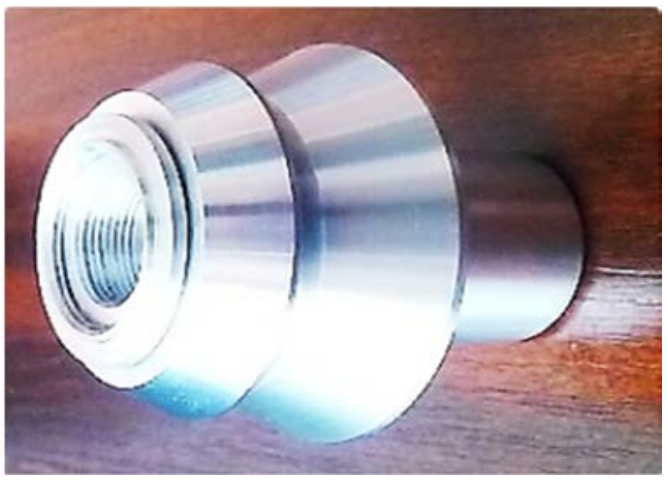

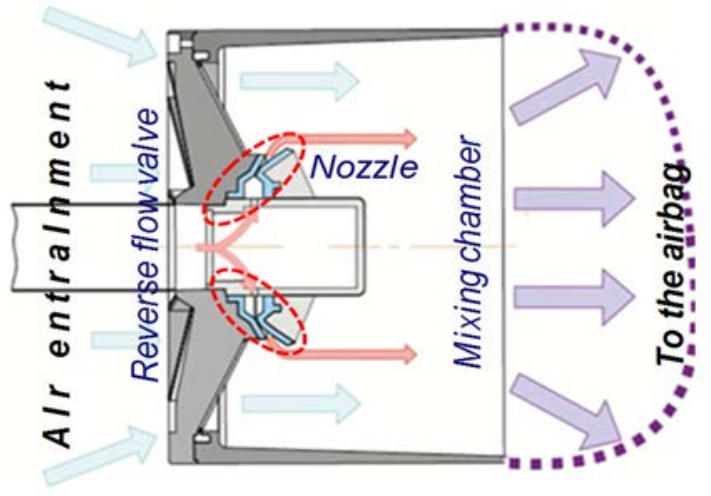

$b$

Fig. 8. The aspirated inflator for experimental testing $(a)$ and the schematic of its operation $(b)$

The aspirator model assembly mounted to the pneumatic facility is shown in Fig. 9, $b$; Fig. 9, $a$ shows location of pressure probes to measure pressure in the pre-chamber (1), dynamic pressure at the exit of the inflator (2 - 10), and static pressure along the wall of a mixing chamber $(11-15)$. 


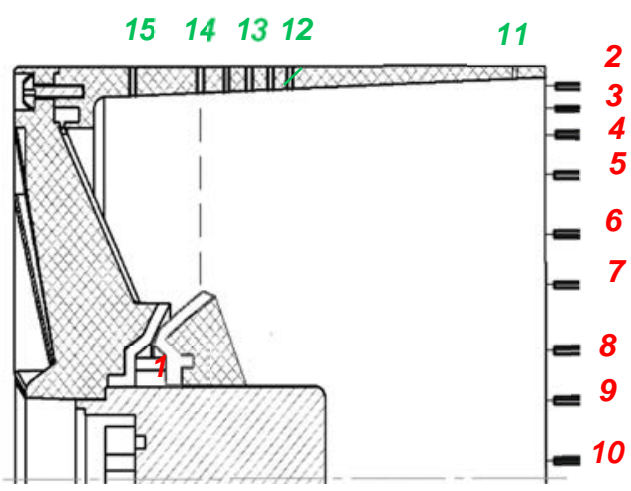

$a$

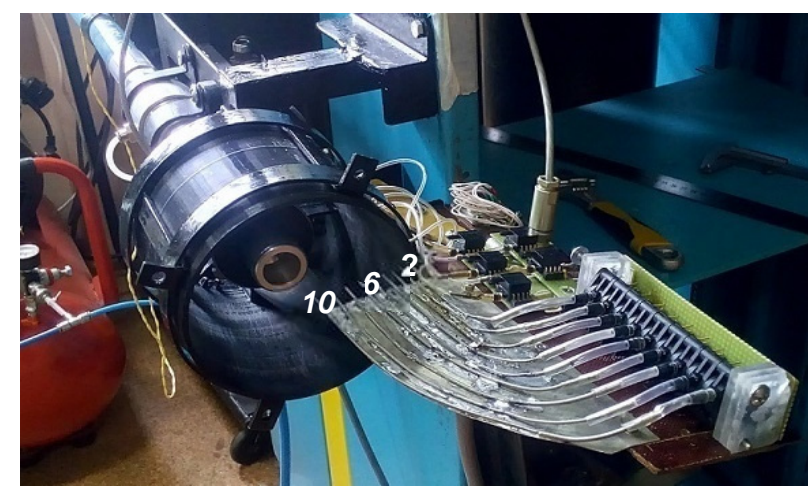

$b$

Fig. 9. The numbering of pressure probes $(a)$ and the assembled inflator system with a pressure probe rake $(b)$

\section{Results and discussion}

\subsection{Aspirator pressure range}

The basic goal of measurements is to determine conditions that provide stable behavior of the supersonic jet and, consequently, stable initiation of the entrainment/aspiration process. Separation effects or just unstable location of the jet in the mixing chamber can deteriorate this process. To mitigate the consequences of the improper flow behavior [12, 13, 15], experimental efforts were focused on finding optimal ranges of parameters such as operational (motive) pressure, $P_{\mathrm{m}}$, for the given aspirator geometry. Patterns of pressure measurements using 15 mentioned probes enable us to reconstruct the flow structure, to determine a dominant jet position within the aspirator housing, and to recommend optimal combinations of parameters. Typical pressure field patterns are shown in Figs. 10, 11.
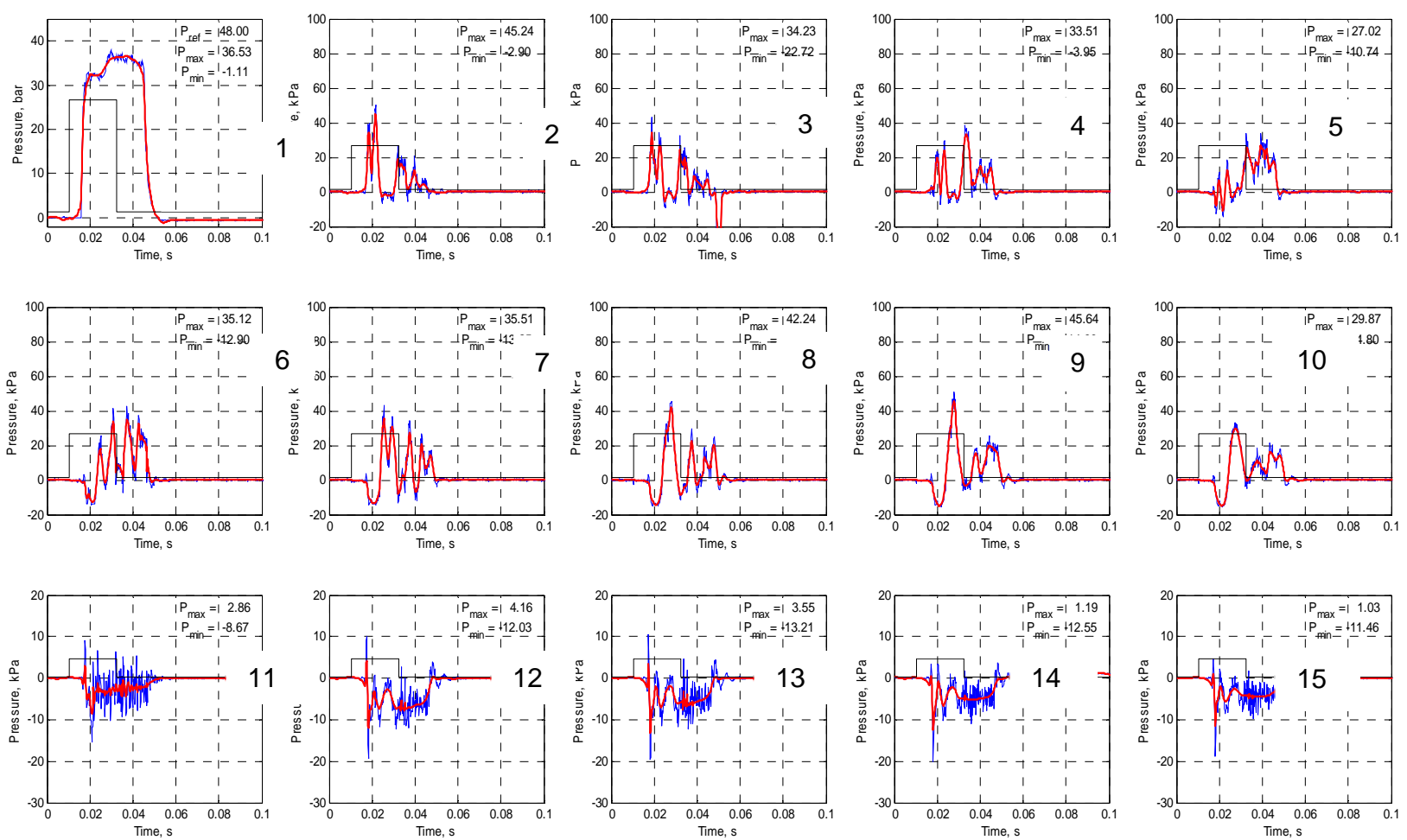

Fig. 10. \#1 aspirator (Fig. 7, a) results of pressure measurement in 15 probe locations shown in Fig. 9: slit, $0.4 \mathrm{~mm}$; pressure, $48 \mathrm{bar}$ 

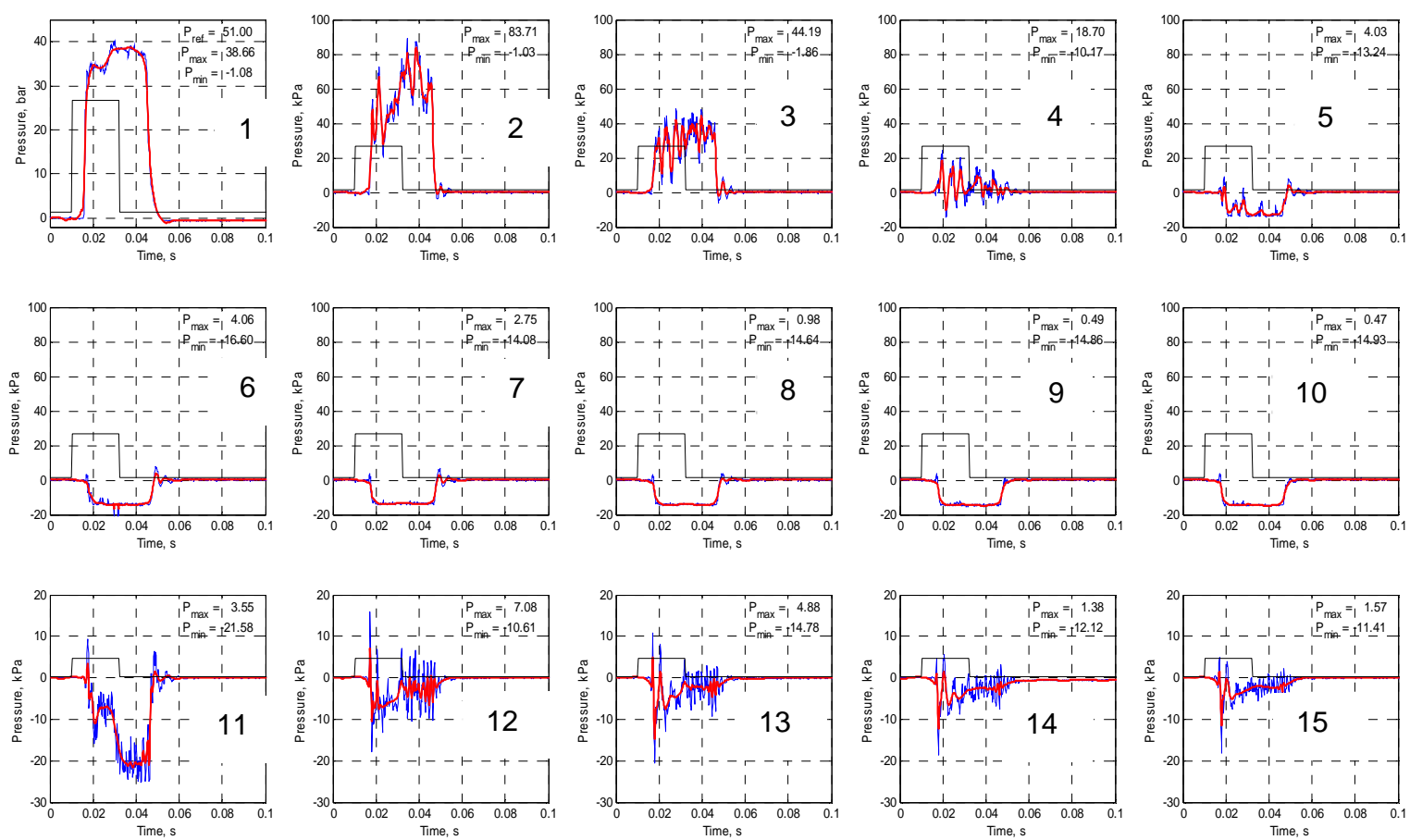

Fig. 11. \#1 aspirator results of pressure measurement in 15 probe locations: slit, $0.4 \mathrm{~mm}$; pressure, 51 bar

Pressure measurement patterns of a type given in Figs. 10 and 11 (\#1 aspirator with the 0.4 mm wide slit) serve as a frame to analyze the jet behavior in time. The initial pressure pulse from a high-speed valve is shown with a black line; red lines show averaged (de-noised) values of pressure measured by different probes. Fig. 10 shows the data registered mainly by \#5 - 10 probes located at an axial part of the aspirator. Fig. 11 shows results for the same aspirator for higher pressure: the signal is detected only by near-wall \#2-4 probes that indicates that the jet moves to the aspirator housing wall.

Figures 12 are deduced from these measurements to illustrate the reconstructed flow field structure in these two cases where the jet is either falling down on the aspirator axis (Fig. 12, $a$ ) or on the mixing chamber wall (Fig. 12, b). Both situations of a dominant jet location show significant decay of the ambient air entrainment in spite of increased motive pressure in the second case.

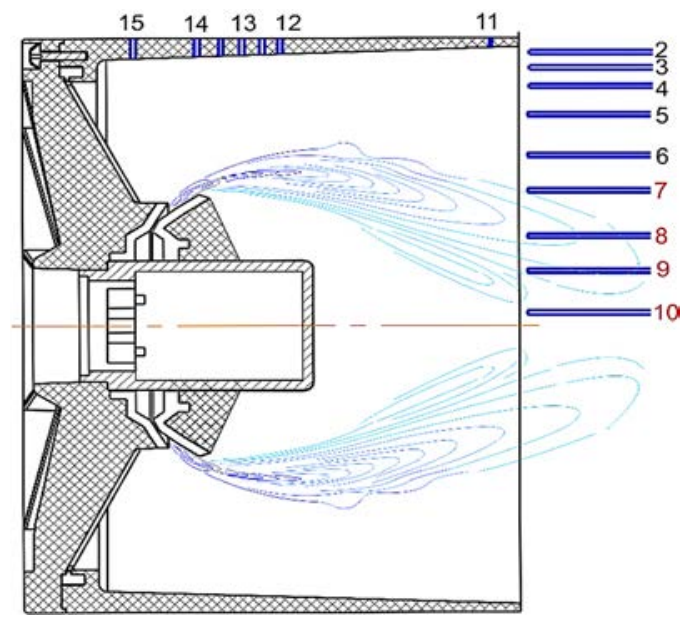

$a$

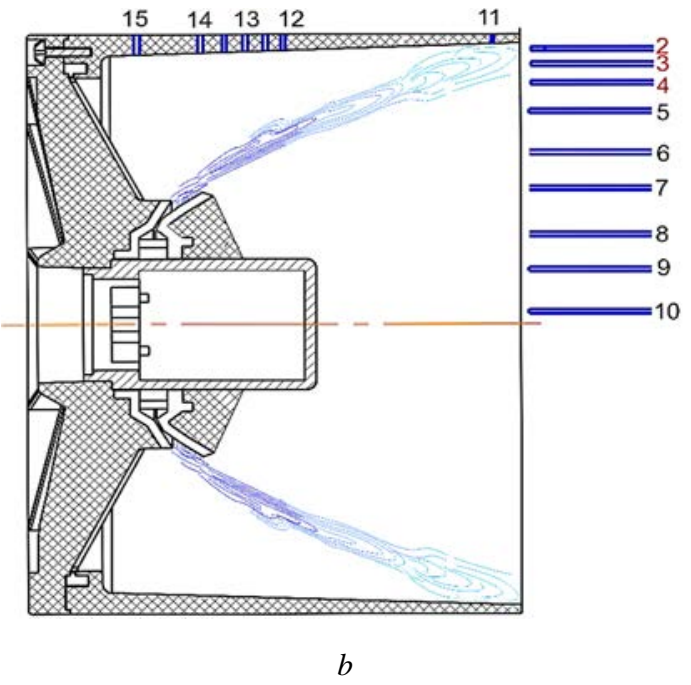

$b$

Fig. 12. Possible supersonic jet behavior within the aspirator: $(a)$ jet falls onto the aspirator axis; $(b)$ jet is directed to the aspirator wall 
The static pressure distribution registered by the \# 11 - 15 probes shows that the area of \#14, 15 probes is under the decreasing vacuum pressure from $\sim 5 \mathrm{kPa}$ in Fig. 10 to $\sim 3 \mathrm{kPa}$ in Fig. 11 with growing high pressure that, accordingly, results in the lower ambient air entrainment. Further increase of high pressure leads to further falling vacuum pressure in this suction area.

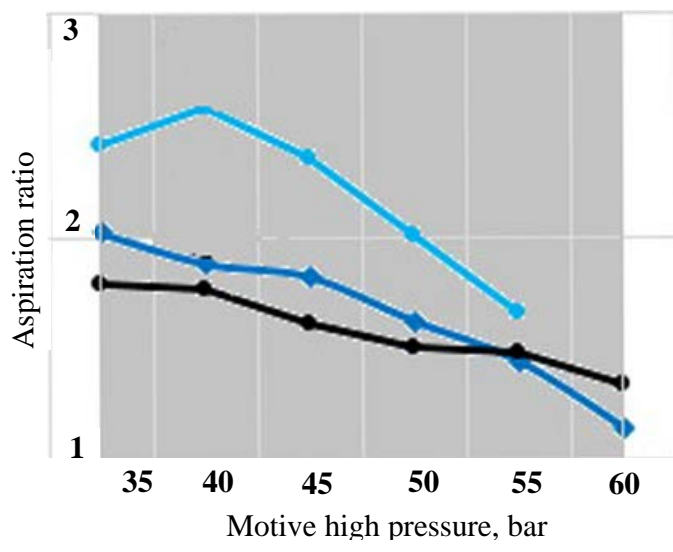

Fig. 13. Aspiration ratio for cold gas depending on pressure: black line - aspirator \#1, blue lines - optimized design [13 - 15]
Thus, the best entrainment can be expected for pressure $1-2$ bars below the pressure resulting in the jet displacement towards the aspirator wall, i.e. the jet located approximately parallel to the aspirator axis and demonstrating its stable behavior.

The satisfaction of the given engineering requirements for the developed aspirator happens to be possible only under conditions of certain compromises concerning the choice of aspirator geometry and a pressure range of its operation. It is well seen in Fig. 13 that shows the aspiration ratio falling with growing motive pressure for a chosen aspirator design. The optimization of design [12 - 15] can result in better air entrainment. In the case of the aspirated inflator operation with a gas generator (hot gas case), the volume aspiration ratio is expected to be roughly doubled.

In this connection, matched with numerical flow simulation, the experimental effort aims at the determination of the optimal ranges of all variable parameters including the operational pressure. As a result, recommendations can be given on optimal sets of parameters. Video-recorded inflation processes of an airbag can substantiate these recommendations.

\subsection{The search for an optimal aspirator design}

The ejecting slit width is a key parameter of the design; the experiments were held for a slit width of $0.25,0.35$, $0.40,0.45,0.50 \mathrm{~mm}$ within a pressure range of $18-55$ bar with $3-6$ bar step. The airbag inflation was tested using \#1 and \#2 inflators; the process was recorded using a high-speed camera.

To eliminate irrelevant losses in the flow path, eight orifices with a diameter of $3.5 \mathrm{~mm}$ were made in the flow tract from the gas-generator substitute high-pressure source) to the pre-chamber (Fig. 7). Their total area was made greater than a narrow area of a circular slit. A lesser area of orifices compared to the circular slit area would cause a large pressure drop within the device: pressure after a slit would be about three times lower than before a slit.

The best inflation was observed for the \#1 aspirator operated with the following parameters: 0.45 mm slit width; 8 orifices of $3.5 \mathrm{~mm}$ diameter; high pressure, $P_{\text {asp }}=45$ bar; inflation time, $\mathrm{t}=40 \mathrm{~ms}$, regulated by a high-speed valve. Fig. 14 shows a sequence of pictures characterizing the airbag inflation in time. Testing the aspirator with a higher pressure of 50 and 55 bar also demonstrated good airbag inflation.

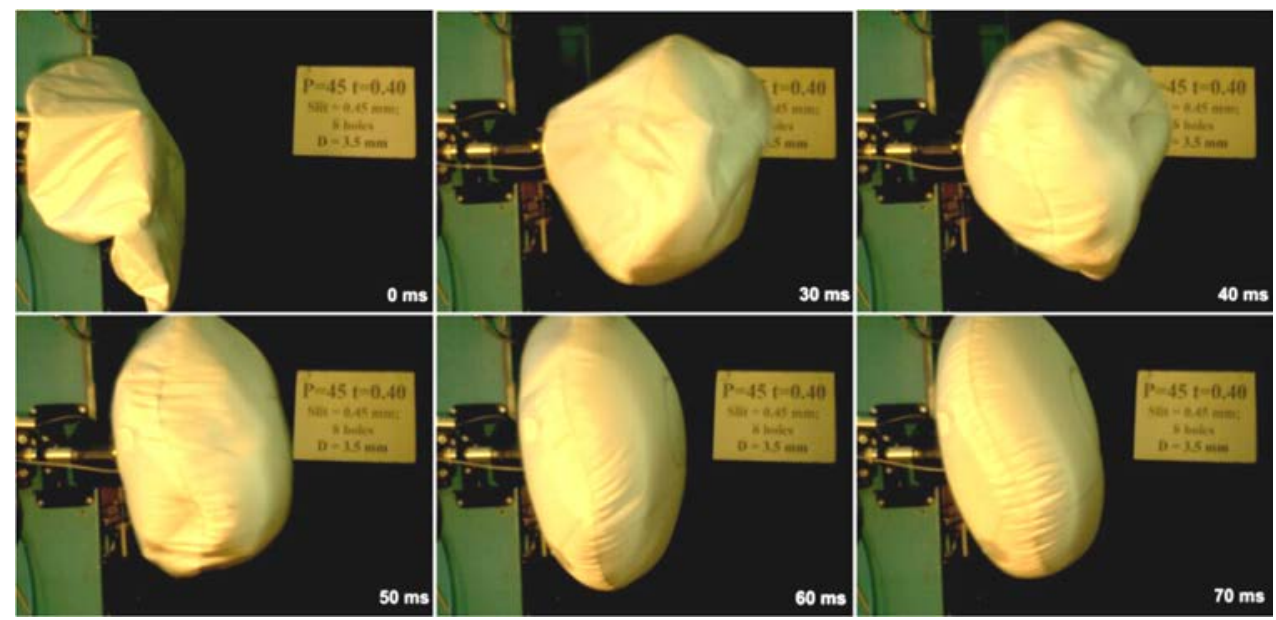

Fig. 14. Airbag inflation process for $\# 1$ aspirator with an optimal combination of parameters: $0.45 \mathrm{~mm}$ slit width; $P_{\text {asp }}=45$ bar; high-pressure open time, $t=40 \mathrm{~ms}$ 
Similar tests were performed with the \#2 aspirator for slit widths of $0.34,0.4 .0 .45 \mathrm{~mm}$ in a pressure range of 18 - 60 bar. For a 0.34 mm slit width, two jet flips were found at pressure 42 and 53 bar, the first one from a wall to the axis, the second one back to the wall. Fig. 15 shows a sequence of best inflation pictures. $0.35 \mathrm{~mm}$ wide slit also demonstrated good results though not as good as those of Fig. 14.
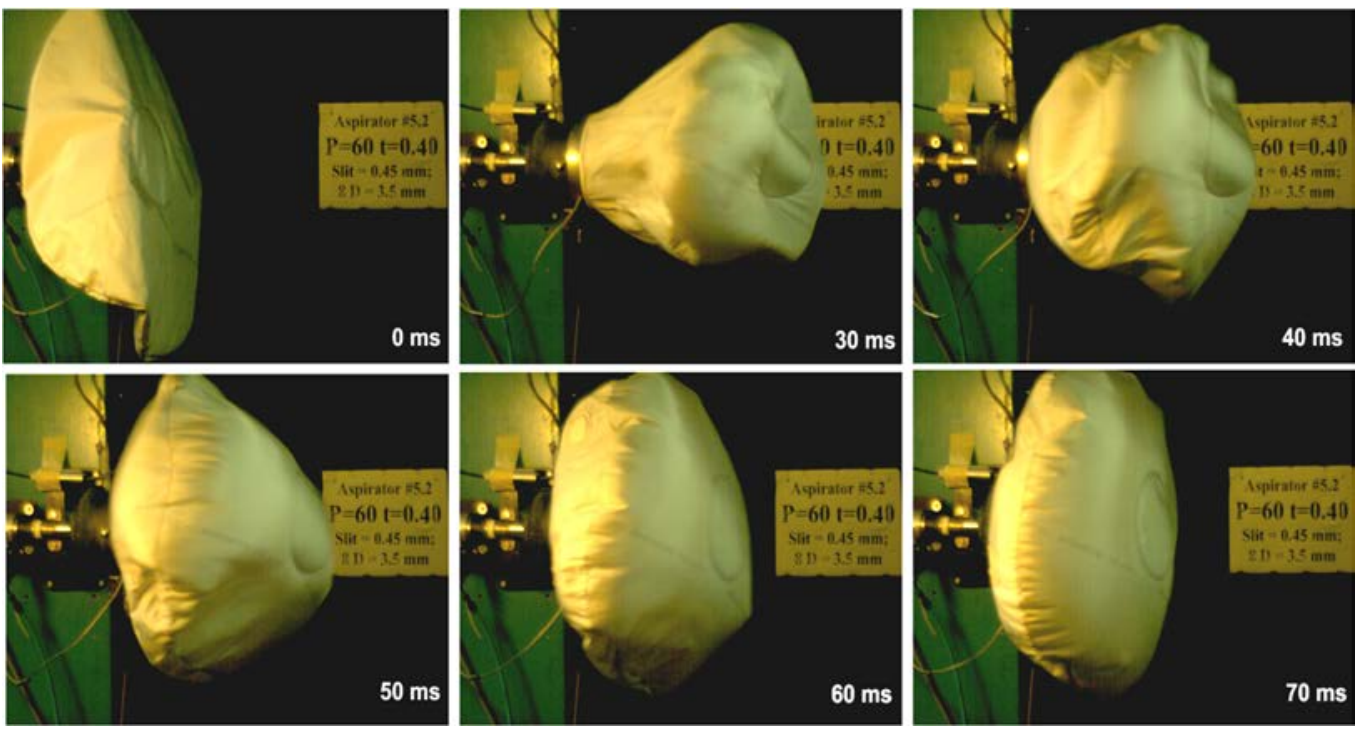

Fig. 15. Airbag inflation process for \#2 aspirator with an optimal combination of parameters: $0.45 \mathrm{~mm}$ slit width; $P_{\text {asp }}=60$ bar; high-pressure open, $t=40 \mathrm{~ms}$

Measurements of pressure fields substantiated visual observations. Successive sets of experiments (aspirator \#1, Fig. 7, a) were carried out for enlarged slit widths as mentioned above in a range of high pressure. When the high pressure was increased to 51 bar, the $0.35 \mathrm{~mm}$ slit design showed a maximum velocity in the peripheral part (\#2 probe) and a reverse flow in its axial part (\#5 to \#10 probes). The $0.4 \mathrm{~mm}$ slit model also located the jet near a wall (\#2, 3 probes) at pressure $21-27$ bar and shifted it to the axis (\#7 - 10 probes) within $30-42$ bar. The situation remained stable up to 50 bar where the jet moved back to the wall (\#2 probe mounted at $1 \mathrm{~mm}$ from the wall).

The $0.45 \mathrm{~mm}$ slit case showed a similar flow situation: the jet located near the wall at 48 bar and the reverse flow in the axial area that was accompanied by a high vacuum static pressure of about $20 \mathrm{kPa}$.

It was concluded that a growing slit width had a stabilizing impact on the ejected jet behavior; in addition, a larger slit area provided higher flow rates even under conditions of available jet instability.

The \#2 aspirator (Fig. 7, b) showed a greater jet instability with a double flip of the jet from the wall to the axis and back with growing pressure

Increasing slit width was found to decrease the pressure of jet flips.

\section{Conclusions}

- Optimal design and operation parameters were sought for the pulsed supersonic ejector applicable in the system of the automobile airbag inflation (aspirated inflator) according to the formulated engineering requirements. As a prototype of the system to be used in practice, the aspirator was developed for testing in the pneumatic compressed (cold) gas facility.

- The aspirator test models were manufactured following the guidance of the numerically evaluated design. A number of models were tested in a range of linear and angular dimensions of their basic elements such as a prechamber, a mixing chamber (housing), and a circumferential slit nozzle forming an air jet responsible for the ambient air entrainment into an airbag.

- As an example, two aspirator designs were compared in terms of their operability evaluated from distributed pressure measurements and inflation process video recordings for various combinations of slit width, high pressure, and inflation time. Certain constraints imposed on a flexible choice of parameters require compromise solutions to optimize the aspirator operation.

- Measurement of pressure fields within the aspirator enabled to reconstruct the flow structure, to analyze the jet behavior and its interaction with the entrained air, and thus to conclude about possible optimal geometry in combination with high-pressure values to provide the expected operational efficiency. 


\title{
Acknowledgments
}

This material is based upon work supported by the Automotive Technologies International, U.S.A. Inc. and Shanghai East Joy Long Motor Airbag Co Ltd. The authors acknowledge with gratitude fruitful cooperation with the numerical simulation team headed by Prof. G. Voropaev, Ukraine.

\section{References}

1. Breed, David S. "Steering Wheel Mounted Aspirated Airbag System”, Granted May 26. - 2015. - United States Patent No. US9039038

2. Breed, D., Voropaiev, G., Yurchenko, N., Paramonov, Yu. and Koshil, A. “Airbag inflators including aspirators”, Int. Publication № WO 2018/132420 A1, published 19 July. - 2018. - Internat. Patent No. PCT/US2018/013088.

3. Breed, D., Zhang, S., Yurchenko, N. and Voropaiev, G. "Development of an aspirated inflator for preventing out-of-position occupant injuries”, Proc. $14^{\text {th }}$ Int. Symposium on Sophisticated Car Safety Systems, Nov. 26-28. - 2018. - Mannheim, Germany.

4. David Breed, Shawe Zhang, Nina Yurchenko, Gennadiy Voropaiev, Nataliya Rozumnyuk, Pavlo Vynogradskyy, Kostyantyn Kuzmenko. "Toward autonomous vehicles: basic aerodynamic background for novel airbag inflation system”, Proc. $14^{\text {th }}$ Int. Symp. on Sophisticated Car Safety Systems, Nov. 26-28. - 2018. - Mannheim, Germany.

5. Tadashi Narabayashi, Yukitaka Yamazaki, Hidetoshi Kobayashi, and Toshihiko Shakouchi. "Flow Analysis for Single and Multi-Nozzle Jet Pump”, JSME Int. J. Series B, Special no on Jets, Wakes and Separated Flows. - 2006. - Vol. 49, No. 4. pp. 933-940.

6. Kyoung-Su Im, Zeng-Chan Zhang, Cook and Grant, O. “Airbag inflator models in LS-DYNA”, $14^{\text {th }}$ International LS-DYNA Conference, Session: Occupant safety, June 12-14. - 2016. - pp. 1-1 - 1-4.

7. Kuzmenko, K.M., Yurchenko, N.F., Vynogradskyy, P.M., and Paramonov, Yu.O. "Optimization of ejector design and operation”. EPJ Web of Conferences. - 2016. - Article Number 02063. https://doi.org/10.1051/epjconf/201611402063

8. Breed, David S., Yurchenko*, Nina F., Vynogradskyy, Pavlo M., Kuzmenko, Konstantin N. and Paramonov, Yuriy A. “Advanced aerodynamic system for airbag inflation”. Proc. Int. Conf. on Advances in Automotive Engineering (ICAAE18), August 27 - 31. - 2018. - Incheon, Korea.

http://www.i-asem.org/publication_conf/structures18/12.ICAAE18/XH3A.1.AE1761_4762F3.pdf

9. Kisil, V.M., Kuzmenko, K.M. and Yurchenko, N.F. "Universal pneumatic high-speed valve UHSV16-1. Proc. of the Conf. "Hydro-Aerodynamics in the Engineering Practice". - 2019. - Kyiv, Ukraine.

10. Yurchenko, N., Vynogradskyy, P., Pavlovsky, R., Zhdanov, O. “Aerodynamic Facility with MW-Systems for Flow Control Based on Localized Plasma Generation”. - 2008. - AIAA Paper-2008-3939.

11. Breauer, Kenneth S. "Sensors, actuators and algorithms for practical implementations of turbulence boundary layer control", Brown University, Div. of Engineering, Box D, Providence. - 2004, pp. 1-24. www.microfluidicd.engin.brown.edu.

12. Kasagi, Nobuhide "Toward smart control of turbulent jet mixing and combustion”, Int. Conf. on Jets, Wakes and Separated Flows, ECJWSF-2005, Toba-shi, Mie, Japan. - 2005. - pp. 1-9.

13. Yurchenko, N. “A method of active boundary-layer control over bodies of complex geometry”, (registered in Ukr. Patenting Office 26.10.2009). - 2009. - Patent of Ukraine № 45240.

14. Yurchenko, N.F. "Energy-efficient flow control around blunt bodies”, Intl. J. of Advances in Aircraft and Spacecraft Science, - 2013.- Vol. 1, - No. 1. - pp. 15-25. http://dx.doi.org/10.12989/aas.2014.1.1.015

15. Breed, David, Yurchenko, Nina, Vynogradskyy, Pavlo, Kuzmenko, Konstantin, Paramonov, Yuriy and Koshil, Andriy. “The Analysis and Experimental Development of Aspirated Airbags for Conventional and Autonomous Vehicles”, Proc. 26th Int.Technical Conf. on the Enhanced Safety of Vehicles (ESV) Eindhoven, Netherlands, June 10-13. - 2019. - pp. 10.

\section{Разработка компактного импульсного эжектора: оценка эффективности по измеренным аэродинамическим характеристикам}

\author{
Н. Ф. Юрченко, П. М. Виноградский
}

Аннотация. Целью исследований является разработка эффективного эжектора, применимого для системы заполнения подушек безопасности автомобилей.

Работа состоит в конструировании эжектора вместе с соответствуюшей экспериментальной установкой и измерительным комплексом. Эксперимент планируется в трех частях: измерение полей давления, скоростная видеосъемка наполнения подушки безопасности с помощуью сконструированного эжектора и измерение коэффициента эжекции (вовлечения, аспирации). С этой целью создано несколько основных элементов. К ним относятся пневматическая установка с ключевым блоком в виде спечиально сконструированного скоростного клапана, система накопления и обработки данных, управляемая удаленно для анализа сигналов с гребенки датчиков давления и стенд для измерения коэффициента эжекции в зависимости от геометрии эжектора и величины мотивирующего давления.

В соответствии с техническим заданием, сверхзвуковые импульсные эжсекторы разработаны и изготовлены в нескольких конструктивных вариантах и испьтаны в Лаборатории Современной Аэродинамики и Междисциплинарных Исследований. Анализ ряда полученных экспериментальных результатов показал их хорочее взаимное соответствие и возможность получения коэффициента эжекции для условий “холодного газа” $A=3.16$ - 1.57 в зависимости от величинь мотивирующего давления. Новое устройство обладает явными преимуществами по сравнению с обычными пиротехническими 
эжекторами: (1) обеспечивает безопасную работу с большими подушками автономных автомобилей, (2) исключает травмирования пассажиров за счет прекращения наполнения подушки при ее контакте с объектом внутри салона.

Ключевые слова: импульсный эжектор, наполнение подушки безопасности, измерение, поля давления, коэффициент эжекции (вовлечения, аспирациии)

\section{Розробка компактного імпульсного ежектора: оцінка ефективності по виміряних аеродинамічних характеристиках}

\section{Н. Ф. Юрченко, П. М. Виноградський}

Анотація. Метою дослідження є розробка ефективного ежектора, щуо може застосовувітися для систем заповнення подушок безпеки автомобілів.

Робота полягає в конструюванні ежектора разом з відповідною експериментальною установкою $і$ вимірювальним комплексом. Експеримент планується в трьох частинах: вимірюванння полів тиску, швидкісна відеозйомка наповнення подушки безпеки за допомогою сконструйованого ежектора і вимірюванння коефіцієнта ежекиї (аспірації). 3 ичією метою створено кілька основних елементів. До них відносяться пневматична установка з ключовим блоком у вигляді спеціально сконструйованого швидкісного клапана, система накопичення та обробки даних, керована дистанційно, для аналізу сигналів з гребінки датчиків тиску $і$ стенд для вимірювання коефіцієнта ежекиії в залежності від геометрї ежектора $і$ величини мотивуючого тиску.

Відповідно до технічного завдання, надзвукові імпульсні ежектори розроблені та виготовлені в декількох конструктивних варіантах $і$ випробувані в Лабораторії Сучасної Аеродинаміки і Міждисциплінарних Досліджень. Аналіз ряду отриманих експериментальних результатів показав їх гарне взаємне узгодження та можливість отримання коефіцієнтів ежекиї для умов “холодного газу” $A=3.16$ - 1.57 у залежності від конфігурациї ежектора та величини мотивуючого тиску. Новий пристрій має явні переваги в порівнянні зі звичайними піротехнічними ежекторами: (1) забезпечує безпечну роботу з великими подушками автономних автомобілів, (2) виключає травмування пасажирів за рахунок припинення наповнення подушки при ї̈ контакті з об'єктом всередині салону.

Ключові слова: імпульсний ежектор, наповнення подуики безпеки, вимірювання, поля тиску, коефічієнт ежекиї (аспірації)

\section{References}

1. Breed, David S. (2015), “Steering Wheel Mounted Aspirated Airbag System”, Granted May 26, United States Patent No. US9039038.

2. Breed, D., Voropaiev, G., Yurchenko, N., Paramonov, Yu. and Koshil, A. (2018), “Airbag inflators including aspirators” , Int. Publication № WO 2018/132420 A1, published 19 July 2018, Internat. Patent No. PCT/US2018/013088.

3. Breed, D., Zhang, S., Yurchenko, N. and Voropaiev, G. (2018), "Development of an aspirated inflator for preventing out-ofposition occupant injuries", Proc. 14 $4^{\text {th }}$ Int. Symposium on Sophisticated Car Safety Systems, Nov. 26-28, Mannheim, Germany.

4. David Breed, Shawe Zhang, Nina Yurchenko, Gennadiy Voropaiev, Nataliya Rozumnyuk, Pavlo Vynogradskyy, Kostyantyn Kuzmenko (2018), “Toward autonomous vehicles: basic aerodynamic background for novel airbag inflation system”, Proc. $14^{\text {th }}$ Int. Symp. on Sophisticated Car Safety Systems, Nov. 26-28, Mannheim, Germany.

5. Tadashi Narabayashi, Yukitaka Yamazaki, Hidetoshi Kobayashi, and Toshihiko Shakouchi (2006), "Flow Analysis for Single and Multi-Nozzle Jet Pump”, JSME Int. J. Series B, Special no on Jets, Wakes and Separated Flows, vol. 49, no. 4, pp. 933-940.

6. Kyoung-Su Im, Zeng-Chan Zhang, Cook and Grant, O. (2016), “Airbag inflator models in LS-DYNA”, 14 ${ }^{\text {th }}$ International LS-DYNA Conference, Session: Occupant safety, June 12-14, pp. 1-1-1-4.

7. Kuzmenko, K.M., Yurchenko, N.F., Vynogradskyy, P.M., and Paramonov, Yu.O. (2016), “Optimization of ejector design and operation”. EPJ Web of Conferences, Article Number 02063. https://doi.org/10.1051/epjconf/201611402063

8. Breed, David S., Yurchenko*, Nina F., Vynogradskyy, Pavlo M., Kuzmenko, Konstantin N. and Paramonov, Yuriy A. (2018), “Advanced aerodynamic system for airbag inflation”. Proc. Int. Conf. on Advances in Automotive Engineering (ICAAE18), August 27 - 31, Incheon, Korea.

http://www.i-asem.org/publication_conf/structures18/12.ICAAE18/XH3A.1.AE1761_4762F3.pdf

9. Kisil, V.M., Kuzmenko, K.M. and Yurchenko, N.F. (2019), "Universal pneumatic high-speed valve UHSV16-1. Proc. of the Conf. "Hydro-Aerodynamics in the Engineering Practice”, Kyiv, Ukraine.

10. Yurchenko, N., Vynogradskyy, P., Pavlovsky, R., Zhdanov, O. (2008), “Aerodynamic Facility with MW-Systems for Flow Control Based on Localized Plasma Generation”, AIAA Paper-2008-3939.

11. Breauer, Kenneth S. (2004), "Sensors, actuators and algorithms for practical implementations of turbulence boundary layer control”, Brown University, Div. of Engineering, Box D, Providence, www.microfluidicd.engin.brown.edu, pp. 1-24.

12. Kasagi, Nobuhide (2005), “Toward smart control of turbulent jet mixing and combustion”, Int. Conf. on Jets, Wakes and Separated Flows, ECJWSF-2005, Toba-shi, Mie, Japan, pp. 1-9.

13. Yurchenko, N. (2009), “A method of active boundary-layer control over bodies of complex geometry”, (registered in Ukr. Patenting Office 26.10.2009), Patent of Ukraine № 45240.

14. Yurchenko, N.F. (2013), "Energy-efficient flow control around blunt bodies”, Intl. J. of Advances in Aircraft and Spacecraft Science, vol. 1, no. 1, pp. 15-25. http://dx.doi.org/10.12989/aas.2014.1.1.015

15. Breed, David, Yurchenko, Nina, Vynogradskyy, Pavlo, Kuzmenko, Konstantin, Paramonov, Yuriy and Koshil, Andriy (2019), "The Analysis and Experimental Development of Aspirated Airbags for Conventional and Autonomous Vehicles", Proc. 26th Int.Technical Conf. on the Enhanced Safety of Vehicles (ESV), Eindhoven, Netherlands, June 10-13, 2019, pp. 10. 